\title{
Effect of Hyperoxia on the Cerebral Circulation of the Newborn Puppy
}

\author{
Charles Kennedy ${ }^{[i 5]}$, Gilman D. Grave, and Jane W. Jehlek \\ Section on Developmental Neurochemistry, Laboratory of Ccrcbral Mctabolism, National Institute of Mental Health, \\ Bethesda, Maryland, USA
}

\begin{abstract}
Extract
Local cerebral blood flow (CBF) in the 2-day-old puppy ranged between 0.58 (superior olive) and $0.07 \mathrm{ml} / \mathrm{g} / \mathrm{min}$ (centrum ovale), with average values in gray matter of the cerebral cortex, deep cerebral structures, and brain stem equal to $0.34,0.38$, and $0.45 \mathrm{ml} / \mathrm{g} / \mathrm{min}$, respectively. Animals of the same age, after being placed in oxygen for $1 \mathrm{hr}$, had a mean arterial oxygen tension $\left(\mathrm{Pa}_{\mathrm{g}}\right.$ ) of $349 \mathrm{~mm} \mathrm{Hg}$; arterial carbon dioxide tension $\left(\mathrm{Pa}_{\mathrm{CO}_{2}}\right.$ ) did not change from the level seen in animals kept in air. The CBF of nearly all structures was 20-30\% lower in the hyperoxic newborns than in control animals. In 3-week-old puppies, CBF ranged between 1.41 (inferior colliculus) and $0.20 \mathrm{ml} / \mathrm{g} / \mathrm{min}$ (centrum ovale), with average values for gray matter in the cerebral cortex, deep cerebral structures, and brain stem equal to $0.61,0.72$, and $0.93 \mathrm{ml} /$ $\mathrm{g} / \mathrm{min}$, respectively. Puppies at this age breathing oxygen attained a mean $\mathrm{Pa}_{()_{2}}$ of $357 \mathrm{~mm} \mathrm{Hg}$; again, $\mathrm{Pa}_{\mathrm{CO}_{2}}$ values were not different from those in air. The oxygen effect on CBF in the 3-week-old animals was less than had been found at 2 days, there being far fewer structures in which the difference was significant. The smallest differences were in white matter $(-11 \%)$. Continuous exposure to oxygen for 1 week, followed by removal of the puppies to air for 2-3 days, resulted in values for CBF which were comparable with those found in control animals.
\end{abstract}

\section{Speculation}

High concentrations of oxygen at ambient pressure alter a number of growth processes of the cell. The vasoconstrictive action of oxygen on cerebral vessels, which is exaggerated in early postnatal life, may be part of a homeostatic mechanism to limit oxygen concentration in the brain when the arterial $\mathrm{P}_{\mathrm{O}_{2}}$ is elevated.

\section{Introduction}

Inhalation of elevated concentrations of oxygen at ambient pressure has been found to cause a mild degree of vasoconstriction of cerebral vessels. This response has been observed directly [37] and has been inferred from quantitative studies in which cerebral blood flow was found to be reduced and cerebrovascular resistance was found to be increased $[12,20,23]$. The mechanism of the vasoconstrictive action is not known and has been attributed to a direct effect of oxygen on vessel walls [29]. Evidence has been presented, however, to indicate that part, if not all, of the action is secondary to hyperventilation and hypocapnia which accompany oxygen inhalation [35]. A slightly more intense but qualitatively similar action of ambient hyperoxia has been observed in retinal vessels $[7,8,30]$, and, during early maturation, when retinal vasculat ture is in a state of formation, the constrictive effect of 
oxygen inhalation is even more pronounced $[3,26]$. If the exposure is prolonged at this time, vessel lumina may be irreversibly obliterated, and following return to air there ensues a series of responses which, in the human infant, may result in retrolental fibroplasia (RLF) [4, 27]. The similarities of the retinal and cerebral circulations with respect to morphology, embryology, and physiologic responses, have led to the speculation that infants who developed RLF might also have comparable abnormalities in the brain. A search for an angiopathy in the brains of infants who have died with RLF and in various animals in which a condition resembling RLF can be produced experimentally, however, has gone unrewarded [4, 26]. Gyllensten [11] pursued the possibility that hyperoxia might cause some abnormality in vascular development in the brain by measuring capillary density with India ink injection techniques. He found that, although vessel morphology was normal, fewer capillaries were present in the cortex of mice raised in oxygen for several days after birth than were present in control animals raised in air. A similar inhibitory effect of oxygen on new vessel formation has also been noted by Ashton in observations on the retina [2].

The present studies were undertaken to examine vasoconstrictor effects of oxygen on the vessels of the developing brain and to determine whether there are any long term consequences of oxygen exposure in the neonatal period on the functional maturation of the cerebral circulation. Regional cerebral blood flow in puppies in the early days of life was quantitatively measured during acute oxygen exposure and after return to air following prolonged exposure. It was found that the cerebral vessels of the newborn dog, like those of the retina, are very sensitive to oxygen and constrict markedly throughout the brain during exposure to high oxygen concentrations. This sensitivity is greatly reduced by 3 weeks of age, uniformly throughout white matter, and in many, although not all, areas of gray matter as well. Prolonged exposure to high oxygen in the newborn period had no persistent effects on blood flow or on the maturation of the cerebral circulation; following return to air, blood flow throughout the brain returned to values normal for the age of the animal [17].

\section{Materials and Methods}

\section{Animals}

Beagle puppies of certified pedigree [38] were used because of uniform genetic background and ability to thrive on bottle feedings begun shortly after birth. Measurements of cerebral blood flow were carried out within 1 or 2 days after arrival in the laboratory, except in the experiments on chronic exposure to oxygen, when the interval was 12-14 days. The animals were maintained on simulated bitch milk [39] given by bottle every 4-6 hr.

\section{Methods}

The ${ }^{14} \mathrm{C}$-antipyrine modification of the autoradiographic method for measuring local blood flow, devised by Kety and his associates [10, 18, 19, 28, 31], was employed with the system for arterial blood sampling modified for use in animals with small blood volume. The procedure involves intravenous infusion of a freely diffusible tracer over a 1 -min period, during which the changing concentration of the tracer is monitored in the arterial blood. At the end of the infusionsampling period, the cerebral circulation is arrested by decapitation; the brain is then frozen and sectioned for autoradiography. Densitometric measurements allow the estimation of tracer concentrations in the various loci in the tissues of the brain. The history of the arterial concentration throughout the period of infusion, together with a knowledge of the partition coefficient between brain tissue and blood, permits the calculation of blood flow per unit weight of brain tissue.

Arterial sampling. Because of the small blood volume of newborn puppies it was necessary to limit blood loss to less than $1 \mathrm{ml}$. The stopcock of the original procedure was replaced by an open catheter to minimize dead space. Drops extruded under arterial pressure were of adequate volume for the determination of tracer concentration, and an empirically designed catheter [40] resulted in a convenient drop rate (25-40 drops per minute). Corrections for the time required for blood to traverse this system, and for the washout properties of the sampling system, were determined in separate experiments. In these experiments, a catheter filled with tracer-free blood was connected to a syringe of a pump [41] which contained blood of known tracer concentration. Care was taken to exclude any air bubbles from the system. At zero time the pump was started, and drops of blood were collected at timed intervals over a 1 -min period. A semilog plot of concentration of tracer against time resulted in a straight line, the slope of which was the washout constant used in the equation to make the proper correction [10]. Constants were determined for different rates 
of flow through the catheter, and the proper constant was selected to correspond with the conditions of any given experiment.

Under light halothane anesthesia, arterial and venous polyethylene catheters were threaded into the descending aorta and inferior vena cava, respectively, via the femoral vessels. The catheters were kept filled with heparin solution [42] until the onset of the measurement. After an interval of 4-6 hr to allow for complete recovery from anesthesia, ${ }^{14} \mathrm{C}$-labeled antipyrine [43], in a close of $200-300 \mu \mathrm{Ci} / \mathrm{kg}$, was infused at a constant rate over a l-min period throughout which arterial samples were collected, drop by drop, at recorded times on filter paper planchets in preweighed plastic vials. During this time the animal was held by hand, and, although free to move, was usually quiet but not allowed to sleep. After the planchet vials were reweighed, the paper on which the blood sample was absorbed was transferred to vials for scintillation counting. Nine milliliters of a dioxane phosphor [44], plus $1 \mathrm{ml}$ of water were added to each vial. After an interval of $24 \mathrm{hr}$, during which time the antipyrine was eluted into the phosphor, the samples were counted [45] without removing the plachet of filter paper from the phosphor. The amount of radioactivity in the vials was determined by calibration of the counting efficiency with an internal standard.

Tissue concentration. After partial removal of soft tissues from the cranium, the head was placed in a Freon-Dry Ice mixture adjusted to a temperature of $-60^{\circ}$. The frozen brain was dissected free of the calvarium and sections, $20 \mu$ in thickness, were made in the cold $\left(-18^{\circ}\right)$ with a microtome [46]. Autoradiograms were made from three serial sections taken every $0.5 \mathrm{~mm}$ throughout the brain. With each film [47] a set of four plastic standards of graded concentration of ${ }^{14} \mathrm{C}$, which had been calibrated against rat brains of known tracer concentrations, was included. The atlas of Adrianov and Mering [1] was used as a guide in identifying regions of the cerebral cortex. Depending on the size of a given cerebral structure, $6-20$ readings of optical density were obtained for each, the mean of which was used to determine tissue concentration for that structure.

Partition coefficient. The partition coefficient for antipyrine between brain and blood was found by Reivich et al. [28] to approximate unity in adult rats. Because of the greater water content in the immature brain than in the adult, it was necessary to obtain values in the young puppy. By means of an autoradiographic procedure [17], a value of 1.0 was obtained for 2-week-old puppies for both white and gray matter. Although this value varies slightly with hematocrit, no correction was made for this variable in the data given here. Small differences in the partition coefficient have a negligible effect on values for blood flow over the range found in this study.

\section{Miscellaneous Procedures}

Just before the infusion-sampling period, $0.6 \mathrm{ml}$ arterial blood was withdrawn for measurement of $\mathrm{pH}$ and gas tensions in an analyzer equipped with micro$\mathrm{CO}_{2}$ and oxygen electrodes [48] which were calibrated with standard gas mixtures before each determination. Mean arterial blood pressure was measured with a damped mercury manometer. Hemoglobin concentration was determined by the method of Evelyn and Malloy [9].

\section{Experimental Design}

Experiments were carried out to determine the acute effects of breathing 80-90\% oxygen at 1 atmosphere on local cerebral blood flow at two ages, 2 days and 3 weeks. The experimental animal was allowed to remain in oxygen for at least $1 \mathrm{hr}$, after which the arterial sample for blood gas and $\mathrm{pH}$ measurement was drawn. Shortly thereafter, the timed procedure for blood flow determination was carried out with the animal still in the oxygen environment. The same procedure was carried out in air on control animals. An additional group of experiments was done on 2-day-old puppies which were placed in an Isolette [49] ventilated with oxygen in the same manner as was done in the acute oxygen-exposure experiments, and kept there for 7-9 days. During this time (7-9 days), oxygen concentration was regularly monitored [50], and the flow of gas was adjusted to maintain an ambient $\mathbf{P}_{\mathrm{O}_{2}}$ of $600-650 \mathrm{~mm} \mathrm{Hg}$. They were then returned to air for 3 days before subjection to the same experimental procedures described above. Littermates, matched for birth weight but raised in air, served as controls.

\section{Results}

\section{Effects of Acute Oxygen Exposure}

The exposure of newborn puppies to an environment of $80-90 \%$ oxygen for $1 \mathrm{hr}$ produced no significant changes in mean arterial blood pressure, arterial $\mathrm{pH}$, and $\mathrm{P}_{\mathrm{CO}_{2}}$ from the values observed in matched littermates breathing air (Table I). The mean arterial oxygen tension rose to only $349 \mathrm{~mm} \mathrm{Hg}$ despite esti- 
Table I. Artcrial pH, $\mathrm{P}_{\mathrm{CO}_{2}}, \mathrm{P}_{\mathrm{O}_{2}}$, blood pressure, and hemoglobin concentrations in puppies during $80-90 \%$ oxygen inhalation

\begin{tabular}{|c|c|c|c|c|c|c|c|c|c|c|}
\hline \multirow[t]{2}{*}{ Animals } & \multicolumn{2}{|c|}{$\mathrm{pII}$} & \multicolumn{2}{|c|}{$\mathrm{PCO}_{2}, \mathrm{~mm} \mathrm{Hg}$} & \multicolumn{2}{|c|}{$\mathrm{P}_{\mathrm{O}_{2}}, \mathrm{~mm} \mathrm{Hg}$} & \multicolumn{2}{|c|}{$\begin{array}{l}\text { Mean arterial blood } \\
\text { pressure, mm Hg }\end{array}$} & \multicolumn{2}{|c|}{$\begin{array}{l}\text { Hemoglobin conc, } \\
\mathrm{g} / 100 \mathrm{ml}\end{array}$} \\
\hline & Air & $\mathrm{O}_{2}$ & Air & $\mathrm{O}_{2}$ & Air & $\mathrm{O}_{2}$ & Air & $\mathrm{O}_{2}$ & Air & $\mathrm{O}_{2}$ \\
\hline \multicolumn{11}{|l|}{ Newborn } \\
\hline Mean & 7.43 & 7.44 & 37.6 & 39.0 & 47.6 & 349 & 56.7 & 57.4 & 14.4 & 12.9 \\
\hline $\mathrm{SE}$ & \pm 0.02 & \pm 0.03 & \pm 2.7 & \pm 2.8 & \pm 2.9 & \pm 48 & \pm 2.1 & \pm 0.9 & \pm 0.09 & \pm 0.9 \\
\hline \multicolumn{11}{|l|}{ 3-week-old } \\
\hline Mean & 7.43 & 7.44 & 36.6 & 38.7 & 74.0 & 357 & 73.7 & $7 \overline{5} .3$ & 9.27 & 8.20 \\
\hline SE: & \pm 0.01 & \pm 0.01 & \pm 0.7 & \pm 1.1 & \pm 1.4 & \pm 21 & \pm 2.3 & \pm 2.4 & \pm 0.27 & \pm 0.43 \\
\hline
\end{tabular}

mated alveolar tensions of greater than $500 \mathrm{~mm} \mathrm{Hg}$, suggesting that in puppies there is a low ventilationperfusion ratio or pulmonary arteriovenous shunting as has been found in newborn infants [21]. Immaturity of pulmonary function was also reflected in the low arterial oxygen tensions of the control animals. Mean values for blood flow in most cerebral structures of the oxygen-exposed newborn puppies were $20-30 \%$ below those observed in the controls, the differences ranging from -8 to $-32 \%$ (Table II). The reduction was statistically significant $(P<0.05)$ in 23 of the 35 structures examined, with a strong trend toward significance in most of the remaining structures. The effect was more or less uniformly distributed in gray and white matter.

In the 3-week-old puppies, acute exposure to high oxygen still proved to be without effect on arterial $\mathrm{P}_{\mathrm{Co}_{2}}, \mathrm{pH}$, and blood pressure (Table I) but lowered the values for cerebral blood flow below those found in control puppies exposed to air (Table II). Reductions at this age, however, were less marked than those seen in the newborn puppies; they ranged from -8 to $-25 \%$, but were statistically significant $(P<0.05)$ in only 8 of the 35 structures. A decreased sensitivity of the cerebral circulation to oxygen was most striking in white matter; the exposure to oxygen reduced blood flow in the white matter by an average of $11 \%$ in the 3 -week-old animals, compared with an average reduction of $24 \%$ in the 2 -day-old puppies.

\section{Effects of Chronic Oxygen Exposure}

In the animals placed in oxygen shortly after birth and maintained there 7-9 days before being returned to air, no differences from values seen in control animals were found in arterial $\mathrm{pH}$, blood gases, or hemoglobin concentration (Table III). Also, values for blood flow were comparable in all cerebral structures except for those in the superior olive, in which there was a $17 \%$ increase (Table IV).

\section{Discussion}

The inhalation of $80-100 \%$ oxygen at ambient pressure has repeatedly' been shown to result in a $10-15 \%$ reduction in cerebral blood flow, both in man and in experimental animals $[12,14,20,23]$. Some degree of hyperventilation usually accompanies the oxygen inhalation, with a resulting depression of arterial $\mathrm{P}_{\mathrm{CO} .2}$. Turner et al. [35] have shown in human subjects that, when arterial $\mathrm{P}_{\mathrm{CO}_{2}}$ is maintained at a constant level during oxygen inhalation, no recluction in cerebral blood flow takes place, indicating that the vasoconstrictive effect is an indirect one resulting from a lowered blood $P_{\text {CO... }}$. Their findings, however, are not in agrecment with those of Jacobsen et al. [14], who, in studies in the adult dog, also maintained alveolar $\mathrm{P}_{\mathrm{CO}, 2}$ constant, yet found a $15 \%$ reduction in cerebral blood flow during $100 \%$ oxygen inhalation. Thus, there remains conflicting evidence regarding the vasoconstrictive action of oxygen on cerebral vessels in the adult. In our study of immature animals, oxygen inhalation produced no evidence of hyperventilation; indeed, the mean arterial $P_{(\mathrm{C})}$, of the animals in oxygen was slightly greater than that found in control animals, although the difference was not significant.

Despite the fact that the $\mathrm{Pa}_{\mathrm{O} 2}$ achieved in the puppies exposed to oxygen was only about $60 \%$ of that achieved during comparable exposure of adults, the effects on cerebral blood flow appeared to be greater. The method used in this study provicles values for blood flow in individual regions rather than average blood flow for the entire brain and does not, therefore, permit direct comparsion of the data with those obtained by others. The regions selected in our study, however, are representative of all the major subdivisions of the brain. In more than $75 \%$ of these regions, values for blood flow in the hyperoxic newborn were at least $20 \%$ lower than those seen in control animals. In only two regions (the vestibular nucleus and the inferior colliculus) were the effects of oxygen less than 
Table II. Local cerebral blood flow in puppies breathing oxygen ${ }^{1}$

\begin{tabular}{|c|c|c|c|c|c|c|}
\hline \multirow{3}{*}{ Structure } & \multicolumn{3}{|c|}{ Ncwborn } & \multicolumn{3}{|c|}{ 3-week-old } \\
\hline & $\begin{array}{l}\text { Control: mean age, } 2 \\
\text { days; no., } 8\end{array}$ & $\begin{array}{c}\text { Experimental: mean } \\
\text { age, } 2 \text { days; no., } 6\end{array}$ & \multirow[b]{2}{*}{ Change, $\%$} & $\begin{array}{l}\text { Control: mean age, } \\
21.5 \text { days; no., } 9\end{array}$ & $\begin{array}{l}\text { Experimental: } \\
\text { mean age, } 21.5 \\
\text { days; no., } 9\end{array}$ & \multirow[b]{2}{*}{ Change, \% } \\
\hline & \multicolumn{2}{|c|}{ Blood fccw,$\overline{\mathrm{ml} / \mathrm{g} / \mathrm{min}}$} & & \multicolumn{2}{|c|}{ Blood flow, $\mathrm{ml} / \mathrm{g} / \mathrm{min}$} & \\
\hline \multicolumn{7}{|l|}{ Cerebral cortex } \\
\hline Visual & $0.28 \pm 0.06^{2}$ & $0.21 \pm 0.02$ & $25 * 3$ & $0.52 \pm 0.04$ & $0.45 \pm 0.04$ & 13 \\
\hline Auditory & $0.33 \pm 0.03$ & $0.24 \pm 0.02$ & $27^{*}$ & $0.66 \pm 0.04$ & $0.50 \pm 0.05$ & $25^{* *}$ \\
\hline Association & $0.32 \pm 0.02$ & $0.24 \pm 0.02$ & $26^{* * *}$ & $0.59 \pm 0.03$ & $0.49 \pm 0.04$ & 17 \\
\hline Sensory & $0.38 \pm 0.02$ & $0.29 \pm 0.02$ & 24 & $0.73 \pm 0.04$ & $0.59 \pm 0.03$ & $20^{* * *}$ \\
\hline Motor & $0.39 \pm 0.03$ & $0.31 \pm 0.02$ & $21^{*}$ & $0.70 \pm 0.05$ & $0.62 \pm 0.03$ & 11 \\
\hline Olfactory & $0.34 \pm 0.03$ & $0.26 \pm 0.02$ & $24^{*}$ & $0.66 \neq 0.02$ & $0.46 \pm 0.02$ & $18^{* * *}$ \\
\hline Frontal & $0.34 \pm 0.02$ & $0.23 \pm 0.02$ & $32 * * *$ & $0.51 \pm 0.04$ & $0.44 \pm 0.03$ & 14 \\
\hline Mcan & $0.34 \pm 0.02$ & $0.25 \pm 0.02$ & $25 * * *$ & $0.61 \pm 0.03$ & $0.50 \pm 0.03$ & $17^{*}$ \\
\hline \multicolumn{7}{|l|}{ Cercbellum } \\
\hline Cortex & $0.33 \pm 0.02$ & $0.25 \pm 0.02$ & $25^{* * *}$ & $0.68 \pm 0.04$ & $0.61 \pm 0.04$ & 11 \\
\hline Nuclei & $0.37 \pm 0.03$ & $0.30 \pm 0.03$ & 20 & $0.82 \pm 0.04$ & $0.74 \pm 0.06$ & 10 \\
\hline \multicolumn{7}{|l|}{ Deep cercbral } \\
\hline Medial geniculate & $0.36 \pm 0.03$ & $0.27 \pm 0.02$ & $26^{*}$ & $1.01 \pm 0.06$ & $0.76 \pm 0.07$ & $25^{*}$ \\
\hline Lateral geniculate & $0.48 \pm 0.04$ & $0.37 \pm 0.03$ & 23 & $0.95 \pm 0.05$ & $0.84 \pm 0.11$ & 11 \\
\hline Thalamus, dorsomedial & $0.44 \pm 0.04$ & $0.31 \pm 0.02$ & $30^{*}$ & $0.54 \pm 0.02$ & $0.49 \pm 0.04$ & 9 \\
\hline Thalamus, ventrolateral & $0.53 \pm 0.05$ & $0.42 \pm 0.03$ & 21 & $0.98 \pm 0.07$ & $0.85 \pm 0.04$ & 13 \\
\hline Hypothalamus & $0.29 \pm 0.02$ & $0.22 \pm 0.02$ & $25^{* *}$ & $0.52 \pm 0.03$ & $0.47 \pm 0.03$ & 9 \\
\hline Hippocampus & $0.33 \pm 0.02$ & $0.23 \pm 0.01$ & $31^{* * *}$ & $0.53 \pm 0.02$ & $0.44 \pm 0.03$ & $17 * *$ \\
\hline Amygdala & $0.30 \pm 0.02$ & $0.22 \pm 0.01$ & $28 * * * *$ & $0.45 \pm 0.03$ & $0.41 \pm 0.03$ & 9 \\
\hline Caudate & $0.31 \pm 0.02$ & $0.24 \pm 0.004$ & $22^{* * *}$ & $0.82 \pm 0.05$ & $0.63 \pm 0.04$ & $23^{* *}$ \\
\hline Mean & $0.38 \pm 0.02$ & $0.28 \pm 0.02$ & $25^{* * *}$ & $0.72 \pm 0.03$ & $0.61 \pm 0.05$ & 15 \\
\hline \multicolumn{7}{|l|}{ Brain stem } \\
\hline Superior olive & $0.58 \pm 0.04$ & $0.40 \pm 0.03$ & $32 * * *$ & $1.19 \pm 0.01$ & $0.98 \pm 0.06$ & $18^{*}$ \\
\hline Inferior olive & $0.43 \pm 0.04$ & $0.31 \pm 0.03$ & $28^{*}$ & $0.81 \pm 0.03$ & $0.66 \pm 0.03$ & $19^{* * *}$ \\
\hline Vestibular nucleus & $0.54 \pm 0.03$ & $0.47 \pm 0.05$ & 14 & $0.99 \pm 0.03$ & $0.87 \pm 0.05$ & 12 \\
\hline Cochlcar nucleus & $0.46 \pm 0.04$ & $0.35 \pm 0.03$ & $24^{*}$ & $0.98 \pm 0.07$ & $0.86 \pm 0.06$ & 13 \\
\hline Oculomotor nucleus & $0.49 \pm 0.04$ & $0.37 \pm 0.03$ & $24^{*}$ & $0.87 \pm 0.04$ & $0.76 \pm 0.05$ & 12 \\
\hline Supcrior colliculus & $0.28 \pm 0.02$ & $0.22 \pm 0.01$ & $23^{*}$ & $0.54 \pm 0.02$ & $0.49 \pm 0.05$ & 9 \\
\hline Inferior colliculus & $0.42 \pm 0.03$ & $0.39 \pm 0.04$ & 8 & $1.41 \pm 0.10$ & $1.34 \pm 0.12$ & 5 \\
\hline Mean & $0.44 \pm 0.03$ & $0.35 \pm 0.03$ & $22.7^{*}$ & $0.93 \pm 0.04$ & $0.81 \pm 0.05$ & 13 \\
\hline Pontine gray matter & $0.35 \pm 0.02$ & $0.26 \pm 0.02$ & $26 * *$ & $0.58 \pm 0.02$ & $0.53 \pm 0.02$ & 9 \\
\hline Spinal gray matter & $0.47 \pm 0.06$ & $0.40 \pm 0.03$ & 15 & $0.71 \pm 0.06$ & $0.63 \pm 0.03$ & 11 \\
\hline \multicolumn{7}{|l|}{ White matter } \\
\hline Optic radiations & $0.08 \pm 0.006$ & $0.06 \pm 0.003$ & $21 *$ & $0.22 \pm 0.02$ & $0.19 \pm 0.02$ & 15 \\
\hline Optic tract & $0.23 \pm 0.02$ & $0.19 \pm 0.01$ & 19 & $0.44 \pm 0.02$ & $0.39 \pm 0.02$ & 11 \\
\hline Internal capsule & $0.21 \pm 0.02$ & $0.17 \pm 0.01$ & 19 & $0.41 \pm 0.03$ & $0.37 \pm 0.01$ & 9 \\
\hline Corpus callosum & $0.11 \pm 0.01$ & $0.09 \pm 0.01$ & 23 & $0.24 \pm 0.02$ & $0.21 \pm 0.02$ & 13 \\
\hline Centrum ovalc & $0.07 \pm 0.01$ & $0.06 \pm 0.005$ & 15 & $0.20 \pm 0.02$ & $0.17 \pm 0.02$ & 13 \\
\hline Cerebcllum & $0.16 \pm 0.01$ & $0.13 \pm 0.01$ & $22^{*}$ & $0.41 \pm 0.02$ & $0.37 \pm 0.03$ & 10 \\
\hline Pons & $0.25 \pm 0.02$ & $0.18 \pm 0.02$ & $30^{*}$ & $0.45 \pm 0.04$ & $0.42 \pm 0.02$ & 8 \\
\hline Pyramids & $0.31 \pm 0.03$ & $0.22 \pm 0.01$ & $29^{*}$ & $0.46 \pm 0.02$ & $0.41 \pm 0.02$ & 12 \\
\hline Spinal cord & $0.31 \pm 0.04$ & $0.25 \pm 0.02$ & 20 & $0.38 \pm 0.03$ & $0.33 \pm 0.01$ & 12 \\
\hline Mean & $0.20 \pm 0.01$ & $0.14 \pm 0.01$ & $24.1^{* *}$ & $0.36 \pm 0.02$ & $0.31 \pm 0.02$ & 11.0 \\
\hline
\end{tabular}

${ }^{1}$ Control animals breathe air; experimental animals breathe $80-90 \%$ oxygen .

${ }^{2}$ Values represent means $t$ standard errors for number of animals indicated.

${ }^{3} P$ values, as determined by $t$ test for group comparisons, are indicated by astcrisks: ${ }^{*}<0.05, * *<0.02, * * *<0.01, * * * *<0.001$.

$15 \%$. It seems reasonable to conclude that average blood flow in the oxygen-exposed neonates is reduced by more than $12-15 \%$, the magnitude of the effect of oxygen on average cerebral blood flow in adult animals and man $[12,14,20,23]$.
The effect of hyperoxia on the cerebral circulation of 2-day-old puppies might be considered to be due, in part, to the removal of an hypoxia-mediated increase in CBE inasmuch as the mean normal $\mathrm{Pa}_{\mathrm{O}_{2}}$ of these animals was $48 \mathrm{~mm} \mathrm{Hg}$. Although $\mathrm{CBF}$ appears to be 
Table III. Arterial $\mathrm{pH}, \mathrm{P}_{\mathrm{CO}_{2}}, \mathrm{P}_{\mathrm{O}_{2}}$ and hemoglobin concentrations in 2-week-old puppies following chronic oxygen exposure ${ }^{1}$

\begin{tabular}{|c|c|c|c|c|c|c|c|c|}
\hline \multicolumn{3}{|c|}{$\mathrm{pH}$} & \multicolumn{2}{|c|}{$\mathrm{PCO}_{2}, \mathrm{~mm} \mathrm{Ig}$} & \multicolumn{2}{|c|}{$\mathrm{P}_{\mathrm{O}_{2}}, \mathrm{~mm} \mathrm{Hg}$} & \multicolumn{2}{|c|}{ Hemoglobin conc, $g / 100 \mathrm{ml}$} \\
\hline & Air & $\mathrm{O}_{2}$ & Air & $\mathrm{O}_{2}$ & Air & $\mathrm{O}_{2}$ & $\Lambda \mathrm{ir}$ & $\mathrm{O}_{2}$ \\
\hline 7.38 & $\pm 0.01^{1}$ & $7.39 \pm 0.01$ & $42.3 \pm 2.3$ & $42.7 \pm 2.3$ & $65.0 \pm 3.1$ & $58.2 \pm 4.8$ & $9.08 \pm 0.94$ & $9.75 \pm 0.74$ \\
\hline
\end{tabular}

1 Values expressed as means $\pm \mathrm{sE}$.

unaffected by moderate levels of hypoxia, there is general agreement that in mature animals $\mathrm{CBF}$ begins to increase when $\mathrm{Pa}_{\mathrm{O}_{2}}$ drops below a threshold level of about $50 \mathrm{~mm} \mathrm{Hg}[6,15,22]$. Four of the newborn control animals had values below level $(32,41,47$, and $48 \mathrm{~mm} \mathrm{Hg}$ ). The corresponding values for $\mathrm{pH}$ and $\mathrm{P}_{\mathrm{CO} 2}$ were normal, however, and behavior was vigorous with respect to feeding, spontaneous activity, and reflex responses; thus, they appeared to be in a normal physiologic state. Although neonates of some other species have higher $\mathrm{Pa}_{\mathrm{O}_{2}}$ values [5, 25, 33, 34], we presume that the arterial $\mathrm{P}_{\mathrm{O}_{2}}$ values reported here are normal for the newborn puppy. The low level may reflect the relative immaturity of the dog at birth. It is possible that a different pattern of response of the cerebral circulation to low $\mathrm{P}_{\mathrm{O}_{2}}$ exists in the neonate than has been found in the adult, but at present there are no data bearing on this possibility.

The great variability of the vascular reactivity to oxygen in the various cerebral structures in 3-week-old puppies suggests that local factors in these regions may be more important in explaining the degree of reactivity than a property of the vasculature itself. Those variables known to be capable of influencing vessel tone are oxygen, carbon dioxide, and $\mathrm{pH}$, tissue levels of which are profoundly altered by changes in local metabolic rate and are believed to be the primary factors in adjusting local blood flow to metabolic demand [24, 32]. During early development all cerebral structures have a sharply rising metabolic rate, but the rate of change and the time at which maximal levels are reached varies for different regions [17]. This changing pattern can be expected to result in corresponding variations in local tensions of the respiratory gases and $\mathrm{pH}$. The finding of blood flow values uniformly lower in oxygen-exposed newborns than those in air could be accounted for by a flooding with oxygen of tissue characterized at this age by a relatively uniform and low oxygen requirement $[13,36]$. The resulting increase in local $\mathrm{P}_{\mathrm{O}_{2}}$ would cause marked vasoconstriction. By 3 weeks of age, when a rise in oxygen consumption has taken place in many regions, a similar flooding with oxygen may result in greater variation in regional $\mathrm{P}_{\mathrm{O}_{2}}$, with loci of high oxygen utilization acting as local sinks. In such regions the tensions of oxygen might not rise as high and vasoconstriction might therefore be less or even absent. This explanation may well account for the reduced effect on white matter at 3 weeks of age, a time when metabolic requirement is maximal and myelin formation is at a peak [16].

Prolonged exposure to oxygen has been shown to result in a reduction of capillary density in the cerebral cortex of newborn mice [11], a finding which suggested the possibility that oxygen might impair the normal maturational increase in CBF which takes place in early postnatal life [17]. Evidence of such impairment, however, was not found. The values for CBF in puppies raised in oxygen and those raised in air were comparable except for the isolated finding of a $17 \%$ increase in one structure, the superior olive. The absence of an effect of chronic oxygen exposure on CBF is not explained by a failure of the elevated $\mathrm{Pa}_{\mathrm{O}_{2}}$ to be sustained, inasmuch as values for $\mathrm{Pa}_{\mathrm{O}_{2}}$ obtained in two puppies, while in oxygen on the 7 th day of exposure, were approximately the same as those obtained after exposure for $\mathrm{l} \mathrm{hr}$. Also, the conditions of the experiment were sufficient to cause vasoproliferative changes in the retina. Although these were minimal and sporadic in the animals in which CBF was measured, they were very pronounced in two puppies exposed to oxygen for a comparable period, but which lived in air for 1 week before the retina was examined histologically. The paucity of findings in the animals in which CBF was measured, and which lived only 2 or 3 days after being returned to air, is only that which would be expected. As Ashton et al. [4] have shown in kittens, a period of 1 week or more is necessary for the full development of the proliferative response which begins with the termination of exposure to oxygen. On the basis of the demonstrated sustained elevation of $\mathrm{Pa}_{\mathrm{O}_{2}}$ and the production of pathologic changes in the retina, there is little doubt that a prolonged hyperoxia existed in the tissue of the puppies raised in oxygen. While this period of hyperoxia did not result in changes in CBF from normal levels for the age, it does not preclude the possibility of some effect on vascular 
Table IV. Local blood flow in puppics previously exposed to oxygen for a prolonged period. ${ }^{1}$

\begin{tabular}{|c|c|c|}
\hline \multirow{2}{*}{ Structure } & \multicolumn{2}{|c|}{ Blood flow, $\mathrm{ml} / \mathrm{g} / \mathrm{min}$} \\
\hline & Control & lexperimental \\
\hline \multicolumn{3}{|l|}{ Cerebral cortex } \\
\hline Visual & $0.41 \pm 0.04$ & $0.41 \pm 0.02$ \\
\hline Auditory & $0.43 \pm 0.03$ & $0.38 \pm 0.02$ \\
\hline Association & $0.45 \pm 0.03$ & $0.41 \pm 0.02$ \\
\hline Sensory & $0.51 \pm 0.03$ & $0.52 \pm 0.02$ \\
\hline Motor & $0.62 \pm 0.04$ & $0.68 \pm 0.06$ \\
\hline Olfactory & $0.46 \pm 0.07$ & $0.45 \pm 0.04$ \\
\hline Frontal & $0.45 \pm 0.04$ & $0.45 \pm 0.03$ \\
\hline \multicolumn{3}{|l|}{ Cerebellum } \\
\hline Cortex & $0.62 \pm 0.06$ & $0.63 \pm 0.06$ \\
\hline Nuclei & $0.70 \pm 0.07$ & $0.71 \pm 0.07$ \\
\hline \multicolumn{3}{|l|}{ Deep cerebral structures } \\
\hline Medial geniculate & $0.58 \pm 0.05$ & $0.62 \pm 0.03$ \\
\hline Lateral geniculate & $0.63 \pm 0.06$ & $0.60 \pm 0.03$ \\
\hline Thalamus, dorsomedial & $0.46 \pm 0.03$ & $0.51 \pm 0.05$ \\
\hline Thalamus, ventrolateral & $0.69 \pm 0.05$ & $0.75 \pm 0.08$ \\
\hline Hypothalamus & $0.41 \pm 0.04$ & $0.42 \pm 0.04$ \\
\hline Hippocampus & $0.43 \pm 0.04$ & $0.43 \pm 0.03$ \\
\hline Amygdala & $0.38 \pm 0.04$ & $0.38 \pm 0.03$ \\
\hline Caudate & $0.49 \pm 0.03$ & $0.51 \pm 0.03$ \\
\hline \multicolumn{3}{|l|}{ Brain stem } \\
\hline Superior olive & $0.83 \pm 0.06$ & $0.97 \pm 0.09^{2}$ \\
\hline Inferior olive & $0.66 \pm 0.07$ & $0.71 \pm 0.07$ \\
\hline Vestibular nucleus & $0.89 \pm 0.09$ & $0.92 \pm 0.09$ \\
\hline Cochlear nucleus & $0.79 \pm 0.06$ & $0.79 \pm 0.06$ \\
\hline Oculomotor nucleus & $0.82 \pm 0.11$ & $0.77 \pm 0.07$ \\
\hline Supcrior colliculus & $0.48 \pm 0.06$ & $0.43 \pm 0.02$ \\
\hline Inferior colliculus & $0.91 \pm 0.11$ & $0.97 \pm 0.06$ \\
\hline Pontine gray matter & $0.52 \pm 0.06$ & $0.57 \pm 0.05$ \\
\hline Spinal gray matter & $0.69 \pm 0.07$ & $0.77 \pm 0.08$ \\
\hline \multicolumn{3}{|l|}{ White matter } \\
\hline Optic radiations & $0.13 \pm 0.02$ & $0.14 \pm 0.01$ \\
\hline Optic tract & $0.29 \pm 0.06$ & $0.31 \pm 0.05$ \\
\hline Internal capsule & $0.32 \pm 0.04$ & $0.36 \pm 0.03$ \\
\hline Corpus callosum & $0.17 \pm 0.03$ & $0.21 \pm 0.02$ \\
\hline Centrum ovale & $0.14 \pm 0.01$ & $0.14 \pm 0.01$ \\
\hline Cercbellum & $0.34 \pm 0.04$ & $0.31 \pm 0.03$ \\
\hline Pons & $0.50 \pm 0.04$ & $0.49 \pm 0.03$ \\
\hline Pyramids & $0.41 \pm 0.03$ & $0.47 \pm 0.04$ \\
\hline Spinal cord & $0.45 \pm 0.05$ & $0.49 \pm 0.04$ \\
\hline
\end{tabular}

${ }^{1}$ Seven pairs of littermates were matched by birth weight. One: member of each pair was placed in $80-90 \%$ oxygen at the age of 2-3 days for a period of 7-9 days and then returned to air for another 2 days, after which the procedure for measuring blood flow was carried out. Mcasurements were performed on the same day as that performed on the matched control raised in air. Mean age for the group was 13.7 days. Values given represent means \pm standard crrors. Analysis by the method of paired comparisons indicated no significant differences, except for a $17 \%$ higher blood flow in the superior olive of animals cxposed to oxygen.

${ }^{2} P<0.05$. development. A histologic study with routine stains of the brains of the oxygen-exposed puppies, however, failed to clisclose any vascular or other abnormality.

\section{Summary}

The effect of both acute and prolonged inhalation of $80-90 \%$ oxygen on the regional circulation of the brain has been studied in 2-day-old and 3-week-old puppies. Measurements of blood flow were made simultaneously in 35 different structures of the brain by means of the autoradiographic method. Oxygen inhalation in the neonate resulted in $\mathrm{Pa}_{\mathrm{O}_{2}}$ levels of 349 $\mathrm{mm} \mathrm{Hg}$ compared with a mean control value of $48 \mathrm{~mm}$ $\mathrm{Hg}$. There were no differences in arterial $\mathrm{P}_{\mathrm{CO}_{2}}, \mathrm{pH}$, and blood pressure between the experimental and control animals. Values for blood flow were 20-30\% lower in nearly all structures in the oxygen-exposed newborns compared with the control animals. At 9 weeks of age, oxygen inhalation resulted in $\mathrm{Pa}_{\mathrm{O}, 2}$ levels comparable with those seen in the 2-day-old, and, again, arterial $\mathrm{P}_{\mathrm{CO}_{2}}, \mathrm{pH}$, and blood pressure were not different from those in the control animals. At 3 weeks of age, however, hyperoxia was accompanied by a lesser reduction of $\mathrm{CBF}$ than had been found at 2 days of age. There was greater variability in the percentage change in the various structures, with white matter least affected $(-11 \%)$. A l-week period of continuous oxygen exposure of newborn puppies, followed by removal to air for 2-3 days, did not produce any major changes in CBF from the levels observed in animals raised in air. The study indicates that cerebral vessels. of the young puppy share with those of the retina a responsiveness to hyperoxia which is exaggerated in the early days of life. Unlike those in the retina, however, the vascular response appears to be reversible.

\section{Addendum}

Application of the chi-square test to the number of structures with a significant reduction in blood flow in 3-week-old puppies (8/35) and the number showing significant reductions in the newborn $(23 / 35)$ clearly indicates a difference in vascular sensitivity to oxygen between the two ages $(P<0.001)$.

\section{References and Notes}

1. Adrunov, O. S., And Mering, T. A.: In: E. F. Domino: Atlas of the Canine Brain. Translated by E. Ignaticff. (Edwards Brothers, Ann Arbor, 1964). Published originally in Russian as a Government Publication of Medical Literature. (Medgiz, Moscow, 1959).

2. Astron, N.: Oxygen and the growth and development of 
retinal vesscls: in vivo and in vitro studies. The $\mathrm{XX}$ Francis I. Proctor Lecture. Amer. J. Ophthalmol., 62: 412 (1966).

3. Asmron, N., AND Cook, C.: Direct observations of the effect of oxygen on developing vessels. Brit. J. Ophthalmol., 38: 433 $(1954)$.

4. Asmon, N., Ward, B., and Serpeli., G.: Effects of oxygen on developing retinal vessels with particular reference to the problem of retrolental fibroplasia. Brit. J. Ophthalmol., 38: 397 (1954).

5. Brimman, R. E.: Arterial $\mathrm{P}_{\mathrm{O}_{2}}$ in the 2-day-old rhesus monkey. Personal communication.

6. Courerce, F. C.: The effect of oxygen lack on the cerebral circulation. J. Physiol. (London), 100: 198 (1941).

7. Cusick, P. L., Benson, O. O., JR., and Boothiy, W. M.: Effect of anoxia and of high concentrations of oxygen on the retinal vessels. Proc. Mayo Clin., 15: 500 (1940).

8. Dorifrey, C. T., Hint., D. W., Marmer, C. M., and Ramalmo, P. S.: Response of retinal blood vessels to changes in respiratory gas pressurcs. J. Physiol. (London), 177: $70 \mathrm{p}$ (1965).

9. Fiveryn, K. A., AND Mar.oy, H. T.: Microdetermination of oxyhemoglobin, methemoglobin and sulfhemoglobin in a single sample of blood. J. Biol. Chem., 126: 655 (1938).

10. FrFygang, W. H., ANn Sokolorf, L.: Quantitative measurement of regional circulation in the central nervous system by the use of radioactive inert gas. In: Advances in Biological and Medical Physics, Vol. 6, p. 263 (Acadcmic Press, New York, 1958).

11. GyIIENSTEN, L.: Influence of oxygen exposure on the postnatal vascularization of the ccrebral cortex in mice. Acta Morphol. Necr.-Scand., 2: 289 (1959).

12. Mryman, A., Pattrison, J. L., JR., and Duke, T. W.: Cerebral circulation and metabolism in sickle cell and other chronic ancmias, with observations on the effects of oxygen inhalation. J. Clin. Invest., 31: 824 (1952).

13. Hinwicr, H. E., AND FA7FKAS, I. F. Comparative studies of the metabolism of the brain of infant and adult rlogs. Amer. J. Physiol., 132: 454 (1941).

14. Jacobson, I., Harper, A. M., and MCDowal., D. G.: The effects of oxygen at 1 and 2 atmospheres on the blood flow and oxygen uptake of the cerebral cortex. Surg. Gynec. Obstet., 119: 737 (1964).

15. Jamfs, I. M., Minllar, R. A., and Purves, M. J.: Observations on the extrinsic neural control of cerebral blood flow in the baboon. Circ. Res., 25: 77 (1969).

16. Krinfopy, C., Grave, G. D., Jrhle, J., and Sokorort, I.: Blood flow to white matter during maturation of the brain. Neurology, 20: $613(1970)$.

17. Kfennedy, C., Grave, G. D., Jfhr.e, J. W., and Sokoloff, L.: Changes in regional cerebral circulation during maturation. Manuscript in preparation.

18. KrTY, S. S.: Theory of blood-tissue exchange and its application to measurement of blood flow. Methods Med. Res., 8: 223 (1960).

19. Kety, S. S., Landau, W. M., Freygang, W. H., Rowt.and, L. P., AND Sokorofr, L.: Estimation of regional circulation in the brain by the uptake of an inert gas. Fed. Proc., 14:85 (1955).

20. Kety, S. S., AND Schmid, C. F.: The effects of altered arterial tensions of carbon dioxide and oxygen on cerebral blood flow and cercbral oxygen consumption of normal young men. J. Clin. Invest., 27: 484 (1948).
21. Koc:H, G.: Alveolar ventilation, diffusing capacity and the A-a $\mathrm{PO}_{2}$ difference in the newborn infant. Resp. Physiol., 4: 168 (1968).

22. Kogure, K., Scheinberg, P., Rexnmuth, O. M., Fujishima, M., ANn Busto, R.: Mechanisms of cerebral vasodilatation in hypoxia. Trans. Amer. Neurol. Ass., 97: 292 (1969).

23. Iambirtsen, C. J., Kough, R. H., Coopfr, D. Y., Emmel, G. L., Lorschke, H. H., AND SCHMDT, C. F.: Oxygen toxicity. Effects in man of oxygen inhalation at 1 and 3.5 atmospheres upon blood gas transport, cerebral circulation, and cerebral metabolism. J. Appl. Physiol., 5: 471 (1953).

24. LASSF, N. A.: Cerebral blood flow and oxygen consumption in man. Physiol. Rev., 39: 183 (1959).

25. Oliver, T. K., Jr., Demis, J. A., ani Bates, G. D.: Serial blood-gas tensions and acid-base balance during the first hour of life in human infants. Acta Paediat. Scand., 50: 346 (1961).

26. P.AT, A.: Oxygen studies in retrolental fibroplasia. IV. Clinical and experimental observations. Amer. J. Ophthalmol., 38: 291 (1954).

27. PATz, A.: The role of oxygen in retrolental fibroplasia. Pediatrics, 19: 504 (1957).

28. Rivicr, M., Jfhle, J., Sokoloff, L., AND Krity, S. S.: Measurement of regional blood flow with antipyrine ${ }^{-14} \mathrm{C}$ in awake cats. J. Appl. Physiol., 27: 296 (1969).

29. SCHndr, C. F., AND Hradrix, J. P.: The action of chemical substances on cerebral blood vessels. Res. Publ. Ass. Res. Nerv. Ment. Dis., 18: 229 (1937).

30. StFkfr, H. O., and Hickam, J. B.: Normal and impaired retinal vascular reactivity. Circulation, $7: 79$ (1953).

31. Sokolore, L.: Local cerebral circulation at rest and during altered cerebral activity induced by anesthesia or visual stimulation. In: S. S. Kety and J. Elkes: The Regional Chemistry, Physiology and Pharmacology of the Nervous System, p. 107 (Pergamon Press, Oxford, 1961).

32. Sokolorf, L., AND KETY, S. S.: Regulation of cerebral circulation. Physsiol. Rev., 40 (suppl. 4): 38 (1960).

33. Stahlman, M., Gray, J., Young, W. C., ann Sifppard, F. M.: Cardiovascular response of the neonatal lamb to hypoxia and hypercapnia. Amer. J. Physiol., 213: 899 (1967).

34. Thrbeault, D. W., Pobrete, E., and Auld, P. A. M.: Alveolararterial $\mathrm{O}_{2}$ and $\mathrm{CO}_{2}$ differences and their relation to lung volume in the newborn. Pediatrics, 41:574 (1968).

35. Tuknik, J., Iambirtsen, C. J., OWen, S. G., Wendel, H., ANi) Chuod, H.: Effects of .08 and .8 atmospheres of inspired p(). upon cerchial hemodynamics at a "constant" alveolar p(C): of $43 \mathrm{~mm} \mathrm{Hg}$ (Abstract). Fed. Proc., 16: 130 (1957).

36. TYiler, D. B., AND VAN Harrevern, A.: The respiration of the developing brain. Amer. J. Physiol., 136: 600 (1942).

37. Worlf, H. G., And Lxisox, W. G.: Cerebral circulation. XII The effect on pial vessels of variations in the oxygen and carbon dioxide content of the blood. Arch. Neurol. Psychiat., 23: 1097 (1930).

38. Hazclton Research Animals, Inc., Cumberland, Va.

39. Esbilac, Borden, Inc., Chemical Division, Sinith-Douglas, Norfolk, Va.

40. Intramedic, PE $50,15 \mathrm{~cm}$ long joined to PE $10,5 \mathrm{~cm}$ long. Clay-Adams, Division of Becton, Dickinson and Company, Parsippany, N. J.

41. Syringe pump series 900 , Harvard Apparatus Company, Millis, Mass. 
42. Sodium heparin, 1000 units/ml, Abbott Laboratories, North Chicago, Ill.

43. Antipyrine- $N^{\prime}-$ methy $] \cdot{ }^{14} \mathrm{C}$, specific activity, approximately 10 $\mathrm{mCi} / \mathrm{mmolc}$. New England Nuclear, Boston, Mass.

44. The phosphor mixture contained $125 \mathrm{~g}$ naphthalene, $12 \mathrm{~g}$ PPO, and $0.3 \mathrm{~g}$ POPOP and was made to 1 liter with 1,4 dioxane.

45. Packard model 3002, Tri-Carb scintillation spectrometer, Packard Instrument Company, Inc., Downers Grove, Ill.

46. Cryo-Cut, American Optical Company, Buffalo, N. Y.

47. Single-coated, bluc-sensitive, medical $\mathrm{x}$-ray film SB-54, Eastman Kodak Company, Rochester, N. Y.

48. System 113-03, Instrumentation Laboratory, Inc., Lexington, Mass.

49. Air Shields, Inc., Hatboro, Pa.

50. Oxygen analyzer, model D-2, Beckman Instrument Company, Fullerton, Calif.

51. Presented in part at the 39th Ammual Mecting of the Society for Pediatric Research, Atlantic City, N. J., May 1969, and at the 22nd Annual Mecting of the American Academy of Ncurology, Bal Harbour, Ilorida, May 1970.

52. The authors gratefully acknowledge the advice and suggestions offered in the course of the experimental work and in the preparation of the manuscript by Dr. Louis Sokoloff.

53. Supported in part by a grant from the Association for the Aid of Crippled Children to the Children's Hospital of Philadelphia.

54. Dr. Kennedy was the recipient of Special Fellowship no. 2 III NB00272-03 from the National Institute of Neurological Diseases and Stroke. He is presently a member of the Dcpartment of Pediatrics, Georgetown University School of Medicine, Washington, D. C.

55. Requests for reprints should be addressed to: CHarl.ES KENNEDY, M.D., Section on Developmental Neurochemistry, Iaboratory of Cerebral Metabolism, National Institute of Mental Health, Bethesda, Ma. 20014 (USA).

56. Accepted for publication January 8, 1971. 